\title{
Influencing Factors of University Students' Innovative Undertaking and Their Effective Integration
}

\author{
Siqin Tan \\ Shanghai Publishing and Printing College, Shanghai, China \\ Email: 174596142@qq.com
}

How to cite this paper: Tan, S. Q. (2020) Influencing Factors of University Students' Innovative Undertaking and Their Effective Integration. Creative Education, 11, 25232528.

https://doi.org/10.4236/ce.2020.1112185

Received: November 7, 2020

Accepted: December 6, 2020

Published: December 9, 2020

Copyright (C) 2020 by author(s) and Scientific Research Publishing Inc. This work is licensed under the Creative Commons Attribution International License (CC BY 4.0).

http://creativecommons.org/licenses/by/4.0/

\begin{abstract}
With the "mass entrepreneurship and innovation" initiated by China to activate the economic body in the market, university students are provided with a good social-economic environment. However, their innovative undertaking is limited by external and internal factors. This paper proposes the method to effectively integrate the influencing factors of university students' innovative undertaking by constructing the concept innovation, cooperative interaction and collaborative guarantee mechanisms and by establishing a social support system.
\end{abstract}

\section{Keywords}

University Students' Innovative Undertaking, Influencing Factor, Effective Integration

\section{Origin of Issues}

As the socialist market economy develops continuously, China's economy has shown strong momentum and resilience. Even under the impact of COVID-19, the economy has achieved positive growth since the second quarter of 2020. Economic development will lead to more employment and entrepreneurial opportunities. However, business insolvency and impeded export are caused by the epidemic inevitably, which results in a reduction in personnel in enterprises. Besides, a large number of university graduates flood into the market, further exacerbating the employment situation. Due to the "mass entrepreneurship and innovation" initiated to activate the economic body in the market, university students are provided with a good social-economic environment. However, due to an increasing number of graduates, they are faced with new obstacles, such as 
low salary, big psychological gap, and low professional matching rate, when choosing employment units. The "post-90s" and "-00s" students have become the main and new forces in the job market. Their career pursuit is centered on self-worth and self-fulfillment. Therefore, more university students prefer to start their own business after graduation, which makes the innovative undertaking the best choice among them. Besides, entrepreneurship not only becomes more urgent and dynamic due to their participation, but also develops into an important engine for economic growth and development. Hence, it is a crucial method to ease university students' employment pressure and to realize their life dream. China has introduced a variety of preferential tax and financial support policies to help with their entrepreneurial dream in a better way. But compared with the aggregate economy, student entrepreneurs can only make a negligible contribution. University students' innovative undertaking, which is advocated by our country, cannot turn out as expected because its internal and external factors not only restrain its development, but also affect its stability and success (Fu, 2020).

\section{Status Quo of University Students' Innovative Undertaking and Analysis of Major Influencing Factors}

1) Development situation of university students' undertaking practice

a) University students are enthusiastic about entrepreneurship, but fail to put it into practice. Even if they do it, they cannot achieve an ideal result.

The enrollment has been expanded year after year in colleges and universities since 2000 . There have been $8,430,000$ graduates by 2019 , and this number is still increasing in successive years, which results in an unprecedented pressure on their employment. Meanwhile, our country also introduces preferential policies for university students to start their own business. Under this circumstance, these students, with a high enthusiasm for entrepreneurship, participate in various start-up competitions or try to start a business in college. However, only a few of them really engage in this undertaking after graduation. Even those who have joined quit quietly after experiencing setbacks. This is because entrepreneurship is a systematic engineering. Firstly, student entrepreneurs should have various self-qualities to start a business with external opportunities. However, not every student entrepreneur, on the one hand, is suitable for entrepreneurship. One the other hand, compared with social entrepreneurs, university students have a higher failure rate because they are not experienced enough. Thus, they cannot adapt to the market economy that is hard and cruel to entrepreneurs due to their idealized and unrealistic management ideas. Besides, they lack necessary capitals and contacts, which further increases their entrepreneurial risk.

b) The society should support university students' innovative undertaking from a more accurate perspective.

The country strongly supports university students to start their own business and offers a lot of preferential policies and facilitating conditions. However, what the country and the society provide is not necessarily what student entrepre- 
neurs want. Therefore, the society should support university students' innovative undertaking more accurately. For example, those who need capitals can apply for government subsidies on entrepreneurship or for start-up loans. But in practice, many student entrepreneurs have to give up the financial support from the government due to various examination and approval materials, complex approval process, and long waiting. They will either seek the private lending at a higher risk or forgo the existing business opportunities.

Colleges and universities, as the hatcheries for university students' innovative undertaking, have introduce the entrepreneurship education to respond to the country's call. However, there are a lot of drawbacks arising at the same time. For example, can the concept of entrepreneurship education be kept throughout the university? Is the course arrangement reasonable? Are the teachers arranged properly? Can the theory be combined with the practice? Most importantly, do students identify with this education? These problems seriously restrict the development of entrepreneurship education in colleges and universities.

In the process of university students' innovative undertaking, social credibility will be improved effectively if relevant subjects can cooperate and interact with each other. Communication and exchange can be established among them based on appropriate supportive polices. Whether the society identifies with and supports university students' innovative undertaking is also a key factor limiting its development. whether the society can provide necessary tolerance and corresponding supports also affects the success of university students' innovative undertaking. The society believe that university graduates should seek a formal career, which accords with the conventional concept that "a good scholar will make an official". If they start a business after graduation, their parents will feel hard to accept it and regard it as "a wrong road".

While constructing the cooperative mechanism, it is more important to establish a collaborative guarantee system. The key of this system lies in the government. The guarantee of university students' entrepreneurship is solemn and should be implemented by legislation. Guarantee Act for University Students' Innovative Undertaking should be enacted at the right time. If it is not the time, special organizations can be set up to manage university students' entrepreneurship and introduce relevant policies. Thus, their innovative undertaking will be guaranteed comprehensively and systemically. The policies issued by different departments should be integrated by removing repeated, conflicted, overlapped, and divided ones. Only in this way can entrepreneurial policies be feasible and can basic departments "try to help student entrepreneurs". With this "one-stop" policy service and "run-once-only" practical operation, student entrepreneurs can devote themselves to the core business of their entrepreneurial enterprises.

In order to enhance university students' entrepreneurial enthusiasm, potential obstacles must be removed when they start their own business. Government sectors should divide the work clearly and provide the intelligent support for students' entrepreneurial projects. The government, as the guide of such projects, should introduce policies to encourage more market main bodies and social stake- 
holders to participate in university students' entrepreneurial activities. Besides, these policies are regarded as a bridge establishing the cooperative partnership among the government, entrepreneurial enterprises, colleges and universities, and research platforms. Cooperative mechanism, for example platforms, should be constructed to create more opportunities for student entrepreneurs and to help them find their niche partners.

2) Analysis on major influencing factors of university students' innovative undertaking

The success of university students' entrepreneurship depends on themselves and the external environment. For this, it is necessary to explore this issue from internal and external influencing factors.

a) Internal influencing factors

In this paper, internal factors refer to students' entrepreneurial idea, comprehensive quality, motivation, professional level, etc.

As everyone knows, it is a long and arduous process to start a business, in which entrepreneurs must be confident in their own morale and patience. That is, student entrepreneurs should be indomitable and unalterable in front of setbacks and be strong-minded to face stress. Otherwise, they will not succeed. The persistent entrepreneurship originates from university students' unremitting pursuit of innovative undertaking, and the strong entrepreneurial motivation is their spiritual impetus. With the solid knowledge of entrepreneurship and the level of expertise, they can choose and determine excellent entrepreneurial projects. Therefore, the students with entrepreneurial spirit will strengthen their study and mastery of professional knowledge and skills and expand the intellectual field. Besides, they will apply the knowledge to practice and develop entrepreneurial enterprises based on this inexhaustible driving force. Also, student entrepreneurs should have some leadership skills to solve the above problems by communicating with employees, clients, and even competitors. Hence, comprehensive quality is one of the crucial factors affecting the development of entrepreneurial enterprises.

b) External influencing factors

In this paper, external factors mainly include national policies, entrepreneurial environment, implementation of entrepreneurship education in colleges and universities, and social acceptance of university students' entrepreneurship.

First of all, university students cannot start a business without the support of national policies. Our country advocates more main bodies to join the market to invigorate the socialist market economy. Under the background of "mass entrepreneurship and innovation", the country pays more attention to university students' innovative undertaking and introduces various policies covering the "financing, business support, and entrepreneurial guidance" so as to encourage such students to devote themselves to entrepreneurship. The current entrepreneurial environment is suitable for university students. With the rapid reform of the economic system in China, innovative entrepreneurial enterprises have be- 
come the bestowed favor of the era. University students are resourceful and willing to study new things, so they are suitable to set up innovative entrepreneurial enterprises. The level of entrepreneurship education affects that of innovative undertaking directly. Colleges and universities are main platforms to improve students' entrepreneurial competence and level. Enterprise mentors will lead them to entrepreneurial practice by on-campus entrepreneurship training and incubation of startup projects. This is the main method adopted by colleges and universities to carry out entrepreneurship education. What's more, student entrepreneurs should learn to coordinate all social resources. For example, they should seek various resources through Internet, accumulate contacts in daily life, and reserve manpower, material resources, business channels and other knowledge and resources to seek better help and support from the society.

\section{Effective Integration of Factors Influencing University Students' Innovative Undertaking (Wang, Liu, \& Tang, 2020)}

\section{1) Concept innovation}

To support university students' innovative undertaking, the whole society, including such students' own ideas, should be innovated. Firstly, the society should be tolerant to student entrepreneurs, which is the core concept to support the social and economic development. Otherwise, their entrepreneurship will not achieve the desired result. Based on the individual needs during their innovative undertaking, the whole society should try to meet the objective needs and provide a comfortable environment that reflects their interest in entrepreneurship, for example, the support from government, colleges and universities, and society. All these issues depend on the legitimacy of university students' innovative undertaking. Thus, it is necessary to guide the ideas of student entrepreneurs, their parents, colleges and universities, governments, and other social institutions and to promote the policies that support their innovative undertaking.

2) Establishment of social support system

a) Government level: optimizing the environment of entrepreneurial policies

The government mainly plays a guiding role when university students start their own business, which is realized by introducing various preferential policies. Therefore, when designating the policies related to university students' entrepreneurship, the government should not only consider the all-round coordination and development of their entrepreneurial enterprises, but also think about their own characteristics and their influence on other social groups. "Functional departments should optimize social resources, implement the service reform, improve their service quality and efficiency, and simplify the approval process of relevant preferential policies." Thus, the government will create a good environment for university students' innovative undertaking, which promotes the establishment of entrepreneurial enterprises and the healthy and orderly development of university students' entrepreneurship. 
Social support is indispensable to university students' innovative undertaking. In this process, social resources should be integrated. For example, university students should pay attention to the change of entrepreneurial policies, seek for the part beneficial to themselves, and thus promote the development of entrepreneurship. In the meantime, the government should provide financial support and technological assistance for enterprises founded by university students. Besides, student entrepreneurs should develop a good relationship with relevant enterprises to facilitate the material supply and product distribution. More importantly, they should establish a good corporate image and keep a good relationship with clients and consumers. At the same time, they should seek technical and material resources from their alma mater.

b) College level: emphasizing the cultivation of entrepreneurial sense and the improvement of entrepreneurial competence

When introducing the entrepreneurship education, colleges and universities should enhance students' understanding of entrepreneurial spirit by practical experience so that they will stick to their choice. Meanwhile, students should be confident in innovative undertaking and improve the self-evaluation based on a better understanding of entrepreneurship. Then, the practical education should be introduced together with theoretical one. Students can know the innovative undertaking in a better way by working in enterprises, factories, and shopping malls. At last, the social network needed by entrepreneurship should be realized to develop and integrate all enterprise resources in the society effectively (Kong \& Feng, 2017).

Furthermore, the curriculum system of entrepreneurship education can be created by setting reasonable courses. It will be a whole-process system for the specific implementation from entrepreneurial cognition to its motivation and then to its behavior. These courses are combined with professional studies to integrate profession with entrepreneurship. Besides, the practical environment, such as simulated entrepreneurship platform, entrepreneurship practice park, social resource interface, etc., is also important to students' innovative undertaking.

\section{Conflicts of Interest}

The author declares no conflicts of interest regarding the publication of this paper.

\section{References}

Fu, C. Q. (2020). Problems and Countermeasures of Innovation and Entrepreneurship Education for University Students. Continue Education Research, 6, 78-81.

Kong, L. Q., \& Feng, Y. (2017). Development Dilemma and Path Transformation of University Students' Entrepreneurship Education under New Normal Conditions. Education and Vocation, 15, 66-71.

Wang, G. F., Liu, X. J., \& Tang, Y. J. (2020). Study on the Integration of Factors Influencing University Students' Entrepreneurial Intention. Shanghai Management Science, 42, 111-118. 